\section{Use of Controlled Water Deficit to Regulate Poinsettia Stem Elongation}

\author{
Peter Alem ${ }^{1}$, Paul A. Thomas, and Marc W. van Iersel \\ Department of Horticulture, The University of Georgia, 1111 Miller Plant \\ Sciences Building, The University of Georgia, Athens, GA 30602-7273
}

Additional index words. bracts, controlled water deficit, fertigation, growth tracking curve, plant growth retardant

\begin{abstract}
Height regulation is crucial in poinsettia (Euphorbia pulcherrima) production for both aesthetics and postharvest handling. Controlled water deficit (WD) offers a potential alternative to plant growth retardants (PGRs) for poinsettia height regulation. We have previously shown that WD can be used to regulate poinsettia stem elongation. However, it is not clear how WD can be used to achieve different plant heights and how it affects aesthetic qualities such as bract size. Our objectives were to determine whether a range of plant heights can be achieved using controlled WD and to investigate possible adverse effects of WD on shoot morphology. Rooted cuttings of poinsettia 'Classic Red' were transplanted into $15-\mathrm{cm}$ pots filled with $80 \%$ peat:20\% perlite (v/v) substrate. Three target heights $(43.2,39.4$, and $35.6 \mathrm{~cm})$ were set at pinching (Day 27) and height tracking curves were used to monitor plants throughout the production cycle (77 days from pinching to finish). Substrate volumetric water content $(\theta)$ was maintained at $0.40 \mathrm{~m}^{3} \cdot \mathrm{m}^{-3}$ (a matric potential of $\approx-5 \mathrm{kPa}$ ) during well-watered conditions and reduced to $0.20 \mathrm{~m}^{3} \cdot \mathrm{m}^{-3}(\approx-75 \mathrm{kPa})$ when plants were taller than desired based on the height tracking curves. Control plants were maintained at a $\theta$ of $0.40 \mathrm{~m}^{3} \cdot \mathrm{m}^{-3}$ throughout the study and had a final height of $51.2 \mathrm{~cm}$. Plants with the $35.6-\mathrm{cm}$ target height exceeded the upper limits of the height tracking curve despite being kept at a $\theta$ of $0.20 \mathrm{~m}^{3} \cdot \mathrm{m}^{-3}$ for 70 days and had a final height of $39.8 \mathrm{~cm}$. The final plant heights in the $39.4-$ and $43.2-\mathrm{cm}$ target height treatments were 41.3 and $43.5 \mathrm{~cm}$, respectively, within the $2.5-\mathrm{cm}$ margin of error of their respective target heights. Relative to control plants, bract area was reduced by $53 \%, 47 \%$, and $31 \%$ in the 35.6-, 39.4-, and $43.2-\mathrm{cm}$ target height treatments, respectively. Our results indicate that WD can be an effective method of height control, but WD may also decrease bract size.
\end{abstract}

Poinsettia height control involves careful application of height regulation without compromising plant quality. The use of PGRs is a standard practice in poinsettia height regulation. However, excessive application of PGRs can result in permanent growth suppression and subsequent stunting of poinsettias as well as reduced bract size (Faust et al., 2001; Lewis et al., 2004; Niu et al., 2002), whereas application of too little PGR may not sufficiently suppress stem elongation. Manipulating the difference between day- and nighttime temperatures (referred to as DIF) also can be an effective method of height control (Berghage and Heins, 1991; Moe et al., 1992). However, DIF is difficult to implement in warm, humid climates such as in the southeastern United States, because of the difficulty of cooling greenhouses in late summer, when shoot elongation of poinsettia

Received for publication 10 Sept. 2014. Accepted for publication 5 Dec. 2014.

This research was funded by the American Floral Endowment and USDA-NIFA-SCRI (award no. 2009-51181-05768).

We thank Sue Dove for technical assistance, Davis Floral for the donation of the cuttings, Dosatron for the donation of the fertilizer injector, and Fafard for donation of the substrate.

${ }^{1}$ To whom reprint requests should be addressed; e-mail peteralem@yahoo.com. is rapid. In addition, when multiple crops are grown in one greenhouse, DIF cannot be used to control growth of individual crops, because all crops are exposed to the same environmental conditions.

The use of WD has been studied as an alternative means of height regulation and requires careful management to achieve desired results. Improperly regulated or excessive WD can result in poor-quality plants (Liptay et al., 1998). Barrett and Nell (1982) showed that increasing the irrigation interval reduced the height of poinsettia, but also decreased bract, leaf, and total shoot dry weight. Just like PGR application, timing of WD application is important for height regulation (Niu et al., 2002). Preferably, height regulation through WD should be used during vigorous vegetative growth, when the stem elongates most rapidly. We have previously shown that a controlled WD, reducing $\theta$ to $0.20 \mathrm{~m}^{3} \cdot \mathrm{m}^{-3}$ as needed, can be an effective method of regulating elongation of poinsettia (Alem, 2014).

The target height of greenhouse crops, including poinsettia, is often determined by market demands or grower preferences (Clifford et al., 2004; Currey and Lopez, 2011; Fisher and Heins, 1995). The desired target height influences how much growth suppression is required during the poinsettia production cycle. Although there is a lot of information about the effects of PGR application rate, concentration, and frequency (e.g., Hammond et al., 2007; Latimer et al., 1999), there is little information about WD as a means of plant height regulation. Drought severity and frequency are known to result in different levels of growth suppression in many species such as salvia (Salvia splendens), Big bend bluebonnet (Lupinus havardii), petunia (Petunia $\times$ hybrida) (Burnett et al., 2005; Niu et al., 2007; van Iersel et al., 2010), and petunia (Barrett and Nell, 1982). Alem (2014) recently reported that controlled WD can effectively regulate poinsettia height without compromising plant quality. In that study, a total of $15 \mathrm{~d}$ of WD reduced plant height by $10 \%(5 \mathrm{~cm})$ compared with that of control plants.

However, application of WD as a means of poinsettia height regulation has not been popular in the past as a result of the risk of excessive stress and plant loss. The use of soil moisture sensor-based precision irrigation systems (Nemali and van Iersel, 2006) can give growers much better control of the severity and duration of the WD, eliminating the risk of excessive drought stress. Such irrigation systems have been tested in greenhouses and nurseries (Chappell et al., 2013) and provide growers with the needed tools to control WD.

We hypothesize that a range of poinsettia heights can be achieved by applying different durations of WD. To test the use of WD as a means of height regulation, the objectives of this study were to determine 1) whether different plant heights can be achieved by application of WD; and 2) how this affects plant quality.

\section{Materials and Methods}

Plant material and growing conditions. One hundred twenty-eight poinsettia 'Classic Red' rooted cuttings were obtained from a commercial greenhouse (Davis Floral, Dewy Rose, GA) on 7 Aug. 2012 and transplanted into $15-\mathrm{cm}$ pots filled with an $80 \%$ peat, $20 \%$ perlite substrate $(\mathrm{v} / \mathrm{v})$ (Fafard 1P; Fafard, Agawam, MA). This cultivar was chosen because of its vigorous growth habit and the resulting need for height control. The plants were grown in a glass-covered greenhouse in Athens, GA, without supplemental lighting or black cloth application. The plants were fertigated with a water-soluble fertilizer (Peters Miracle Gro Excel 15-5-15 Cal-Mag; $15 \mathrm{~N}-2.2 \mathrm{P}-12.5 \mathrm{~K}$; Scotts, Marysville, $\mathrm{OH}$ ) with a nitrogen concentration of $200 \mathrm{mg} \cdot \mathrm{L}^{-1}$. Fertilizer solution was injected into a drip irrigation system with $2 \mathrm{~L} \cdot \mathrm{h}^{-1}$ pressure-compensating emitters (WPCJ10, Netafim USA, Fresno, CA) through a water-powered fertilizer injector (Dosatron D14MZ2-14 GPM, Clearwater, FL). Plants received fertilizer solution at every irrigation event. This fertilizer was chosen because it has high levels of magnesium and calcium, which are important for poinsettia growth (Bierman et al., 1990). Plant spacing was 6.5 plants $/ \mathrm{m}^{2}$.

The greenhouse was cooled using a pad and fan system when the air temperature was 
above $22{ }^{\circ} \mathrm{C}$, whereas the greenhouse heating was on at temperatures below $18{ }^{\circ} \mathrm{C}$. Temperature set points were the same for day and night. As a result of the large radiative heat load in late summer, actual greenhouse temperature on most days was well above the $22{ }^{\circ} \mathrm{C}$ cooling set point during late summer and early fall. Relative humidity (HMP50; Vaisala, Woburn, MA) was measured at 5-min intervals and photosynthetic photon flux $(P P F)$ (QSO-sun; Apogee Instruments, Logan, UT) was measured every $20 \mathrm{~s}$. Both sensors were connected to a data logger (CR10X; Campbell Scientific, Logan, UT). The $P P F$ data were used to determine the daily light integral (DLI). The DLI on sunny days decreased from 23 to $14 \mathrm{~mol} \cdot \mathrm{m}^{-2} \cdot \mathrm{d}^{-1}$ over the course of the experiment and was as low as 11 to $12 \mathrm{~mol} \cdot \mathrm{m}^{-2} \cdot \mathrm{d}^{-1}$ on cloudy days. Relative humidity averaged $68 \%$.

The plants were pinched $27 \mathrm{~d}$ after transplanting to a height of $\approx 22 \mathrm{~cm}$ (measured from the bench), leaving five to seven nodes, typical of commercial poinsettia production protocols (Faust and Heins, 1996). Plant height was monitored every 2 to $3 \mathrm{~d}$ on the same two plants in each experimental unit, starting immediately after pinching. Height tracking curves were developed with software from the University of Florida, Department of Environmental Horticulture (Gainesville, FL). These tracking curves are developed by entering the pinching date, plant height at pinching, target height, and the expected production duration from the time of pinching ( $77 \mathrm{~d}$ ) into the spreadsheet. The software then fitted a sigmoidal curve describing target heights throughout the production period. Measured heights were plotted along with the height tracking curves to compare actual height with the target height at a particular date. When the average height of plants in a particular treatment was greater than the target height, plants were exposed to WD until their height was within the target range again. A fungicide drench, with a mixture of Subdue maxx (Syngenta, Switzerland) and 3336 (Cleary Chemical Corporation, Dayton, NJ), was applied on 5 Sept. 2012 to control soilborne pathogens.

Height control. Substrate water content was maintained at $0.40 \mathrm{~m}^{3} \cdot \mathrm{m}^{-3}$ when plant height was within the target range and reduced to $0.20 \mathrm{~m}^{3} \cdot \mathrm{m}^{-3}$ to apply WD when height regulation was needed. A WD level of $0.20 \mathrm{~m}^{3} \cdot \mathrm{m}^{-3}$ was chosen based on our previous work showing that this level of WD effectively reduces height without unacceptable effects on plant growth and quality (van Iersel et al., 2010; Zhen et al., 2014). A soil moisture sensor-controlled irrigation system, similar to the one described by Nemali and van Iersel (2006), was used to maintain $\theta$ at the desired thresholds. The irrigation system used two capacitance soil moisture sensors (EC-5; Decagon, Pullman, WA) per plot. The two sensors were inserted diagonally in the root zone of two representative plants in each experimental unit. The capacitance soil moisture sensors were connected to a data logger (CR10X; Campbell Scientific) using two

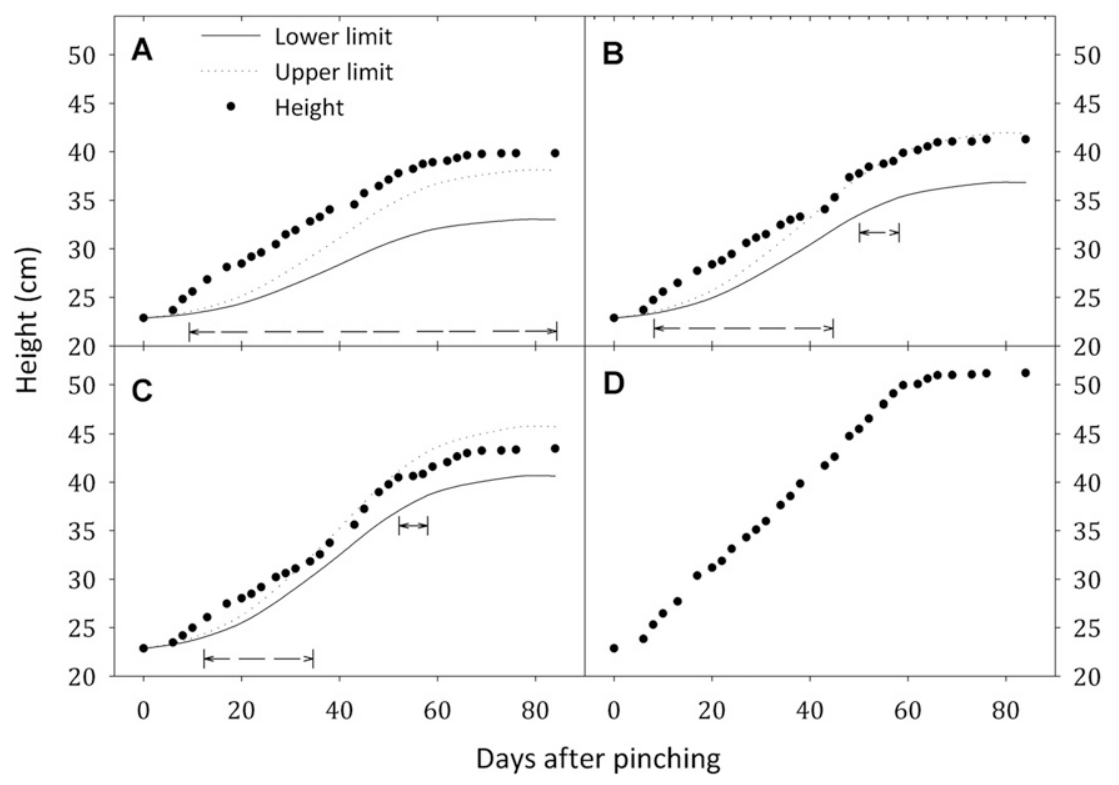

E्
$\frac{0}{\frac{0}{0}}$
$\frac{0}{1}$

Fig. 1. Plant height and sigmoidal height tracking curves with 35.6- $\mathrm{cm}(\mathbf{A}), 39.4-\mathrm{cm}(\mathbf{B})$, and $43.2-\mathrm{cm}(\mathbf{C})$ target heights as well as control plants (D). The upper and lower limits curves are based on final target heights $\pm 2.54 \mathrm{~cm}$. Horizontal arrows indicate times the plants were exposed to a water deficit (substrate water content of $0.20 \mathrm{~m}^{3} \cdot \mathrm{m}^{-3}$ ).

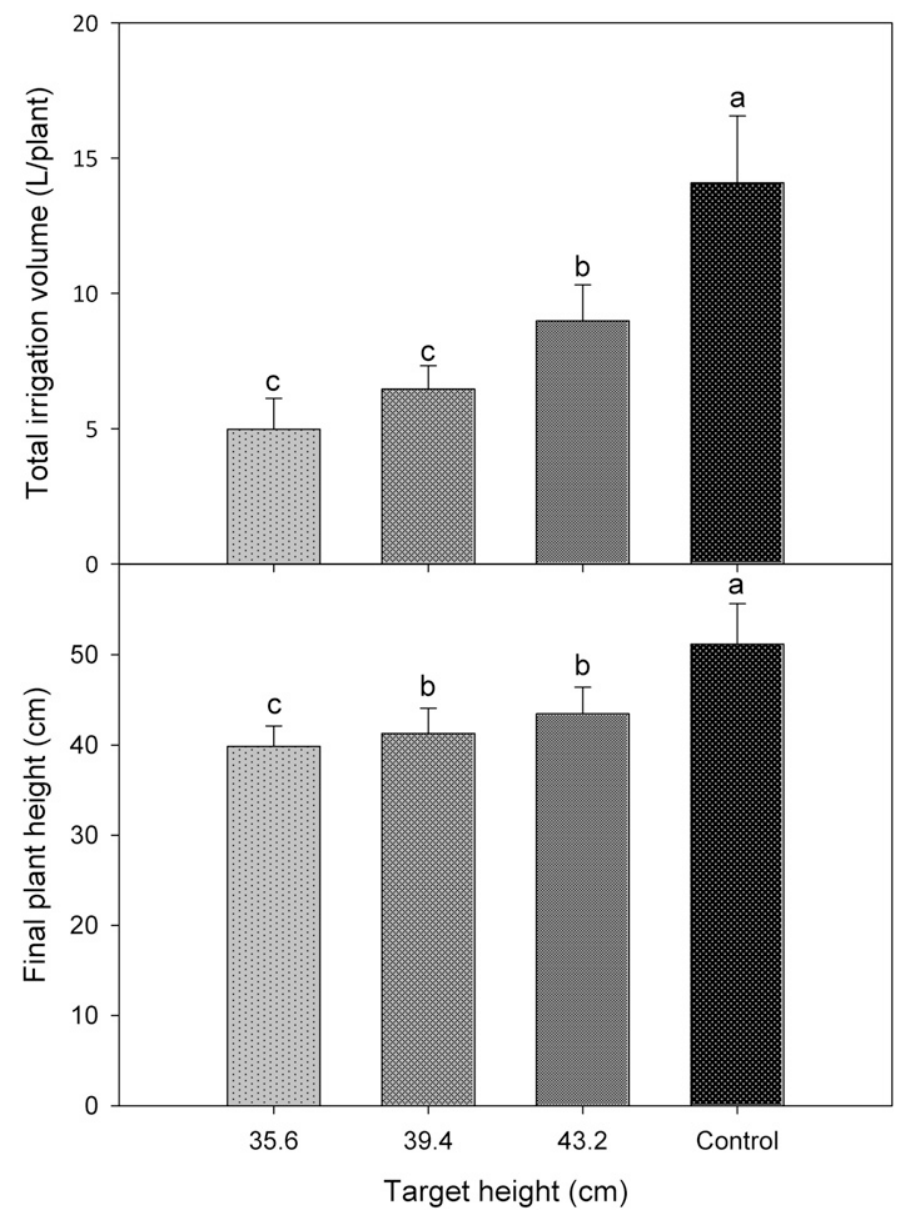

Fig. 2. Final plant height and total irrigation volume of water deficit-treated and control plants at the end of the experiment. Bars (means $\pm \mathrm{SD}$ ) with the same letter are not significantly different according to Tukey's test $(P=0.05)$. Plants with a target height of $35.6 \mathrm{~cm}$ were taller than the upper limit of the target height tracking curve. 
multiplexers (AM16/32; Campbell Scientific). The data logger measured the voltage output from the soil moisture sensors every 10 min using a 2.5 -VDC excitation voltage. The voltage readings were then converted to $\theta$ using a substrate-specific calibration $\left(\theta=\right.$ voltage $\left.\times 1.8862-0.5624, r^{2}=0.95\right)$. Whenever the average $\theta$ fell below the threshold $\theta$ ( 0.40 or $0.20 \mathrm{~m}^{3} \cdot \mathrm{m}^{-3}$ during WD application), the data logger sent a signal to a relay controller (SDM-CD16AC; Campbell Scientific), which opened a solenoid valve (DV; Rain Bird, Azusa, CA) to irrigate the plants for $20 \mathrm{~s}$ with $11 \mathrm{~mL}$ of water at each irrigation. The data logger also recorded the number of times each of the plots was irrigated each day, and these data were used to calculate to daily water use.

Final target plant heights were set at 43.2, 39.4 , and $35.6( \pm 2.5) \mathrm{cm}$ (from the bottom of the pot to the top of plant). Control plants were grown without any height regulation. When the plant height was above the target range as determined by the height tracking curves, $\theta$ was reduced to $0.20 \mathrm{~m}^{3} \cdot \mathrm{m}^{-3}$ to apply WD. Substrate water content was kept at $0.20 \mathrm{~m}^{3} \cdot \mathrm{m}^{-3}$ until plant height was within the target range, after which $\theta$ was increased back to $0.40 \mathrm{~m}^{3} \cdot \mathrm{m}^{-3}$. The average $\theta$ values were recorded by the data logger every $2 \mathrm{~h}$.

Data collection. To determine the relationship between $\theta$ and substrate matric potential, a tensiometer with a pressure transducer (T5; UMS, Munich, Germany) was inserted into one pot with a soil moisture sensor in a $43.2-\mathrm{cm}$ target height treatment. Tensiometer data were recorded by the data logger as well. Matric potential is a measure of how tightly the water is held by the substrate and thus a more direct indicator of plant water availability than $\theta$ (van Iersel et al., 2013).

The two plants from each experimental unit that had soil moisture sensors inserted in their root zone were harvested at the end of the experiment, their bracts were detached from the stem, and total bract area was determined using a leaf area meter (LI-3100; LI-COR, Lincoln, NE). The number of nodes and internodal length were measured on the dominant branch (the uppermost branch from the point of pinching). The shoots were dried in an oven at 75 to $80{ }^{\circ} \mathrm{C}$ for 1 week to determine shoot dry weight.

Experimental design and statistical analysis. The experimental design was a randomized complete block with eight blocks and four treatments (three target heights and a control). Blocking was done to account for temperature and humidity gradients that may exist along the greenhouse bench as a result of the pad and fan cooling system. The experimental unit was a group of four plants irrigated using the same solenoid valve. However, only the two plants in the middle were used for data collection to prevent edge effects. Data were subjected to regression or analysis of variance (proc GLM, SAS 9.3; SAS Institute, Cary, NC). Treatment means were separated using Tukey's honestly significant difference.

\section{Results and Discussion}

Height tracking. Plant height increased rapidly after pinching and exceeded the upper limit of the target range within $6 \mathrm{~d}$ in all three treatments with target heights. This is consistent with the findings of Berghage and Heins (1991), who found that the first internode on the lateral branches is the longest and matures the fastest with internodes becoming shorter because they are closer to the inflorescence. Because lateral branches had already formed and were elongating at the time of pinching, this explains the rapid initial height increase. Thus, for effective height control, it may be important to apply WD early, perhaps even before pinching, to reduce this initial rapid elongation of the proximal internodes of the lateral branches.

Plant height in the 35.6- $\mathrm{cm}$ target height treatment remained above the upper limits of its tracking curve, despite being kept under WD from $8 \mathrm{~d}$ after pinching until the end of the experiment (Fig. 1A). The WD was not severe enough to elicit the required height control to achieve this short target height. Plants in the 39.4-cm target height treatment exceeded the upper limit of their tracking curve at $8 \mathrm{~d}$ after pinching, at which time WD was applied to slow stem elongation. Plant height in the 39.4- $\mathrm{cm}$ target treatment remained above the tracking curve limit for 5 weeks under WD (Fig. 1B). Thereafter, $\theta$ was maintained at $0.40 \mathrm{~m}^{3} \cdot \mathrm{m}^{-3}$ for 1 week before a second, 7-d cycle of WD was needed. After the second WD application, plant height in the $39.4-\mathrm{cm}$ target height treatment remained within its tracking curve limits until the end of the experiment. Thus, to achieve the target height of $39.4 \mathrm{~cm}$, the plants were subjected to WD for $42 \mathrm{~d}$ ( $50 \%$ of the growth duration after pinching).

The 43.2-cm target height treatment was subjected to the shortest duration of WD to maintain plant height within the tracking curve limits. The first WD application in the $43.2-\mathrm{cm}$ target height treatment was started 2 weeks after pinching and lasted 20 d. Plants were then maintained at 0.40 $\mathrm{m}^{3} \cdot \mathrm{m}^{-3}$ for $18 \mathrm{~d}$ before the application of a second, 5-d WD cycle. The height of these plants subsequently remained within the target range.

The control plants were tallest during the entire experiment period. The height of control plants increased linearly from 5 to $60 \mathrm{~d}$ after pinching with an elongation rate of $0.5 \mathrm{~cm} \cdot \mathrm{d}^{-1}$. Although proximal internodes typically

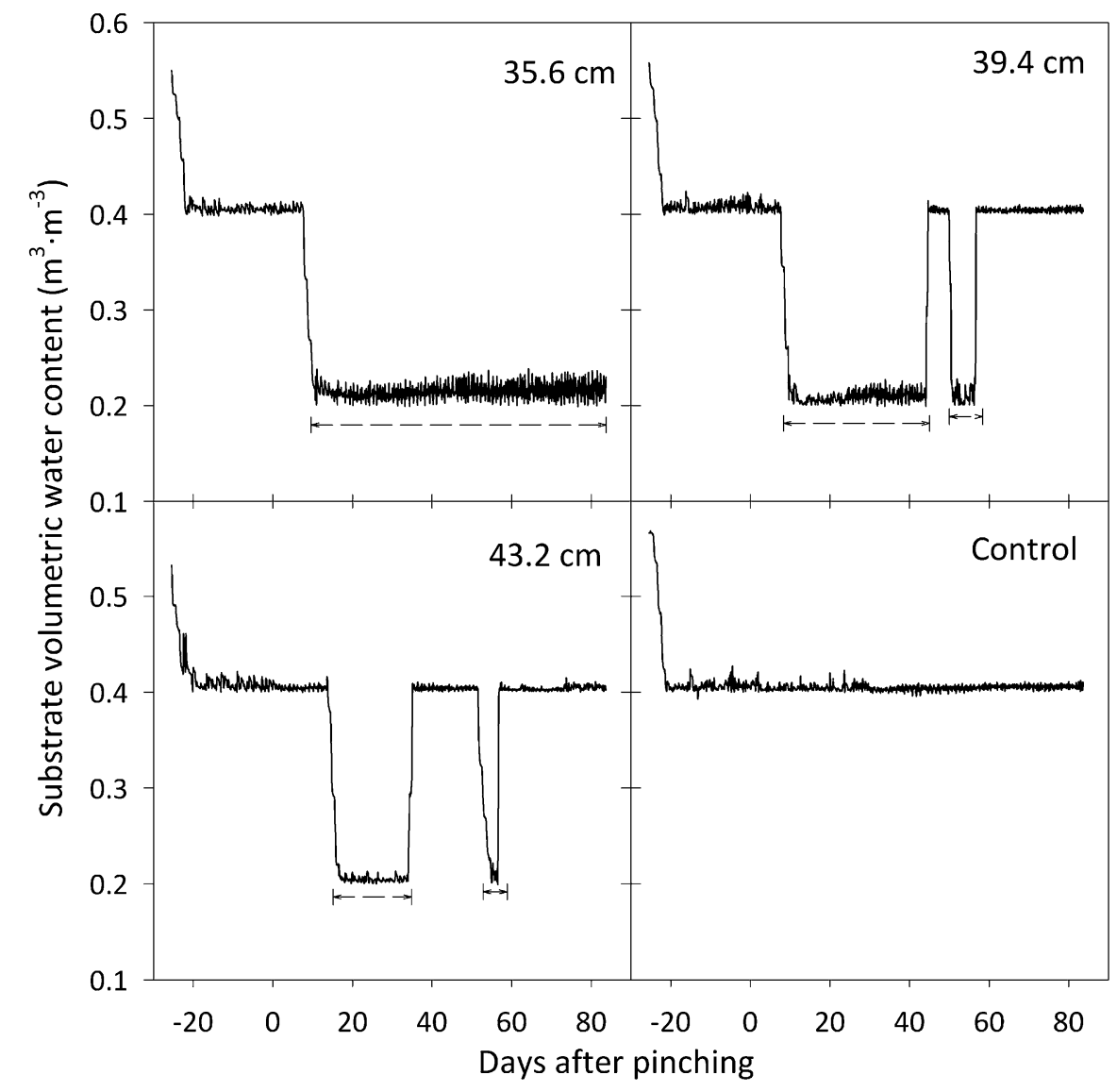

Fig. 3. Substrate volumetric water content $(\theta)$ as maintained by the soil moisture sensor-controlled drip irrigation system in the control, $35.6-\mathrm{cm}, 39.4-\mathrm{cm}$, and $43.2-\mathrm{cm}$ target height treatments. Control plants were kept at a constant $\theta$ of $0.40 \mathrm{~m}^{3} \cdot \mathrm{m}^{-3}$, whereas the $\theta$ in the other treatments was reduced to $0.20 \mathrm{~m}^{3} \cdot \mathrm{m}^{-3}$ (water deficit) when height control was needed. Horizontal arrows indicate periods of water deficit. 

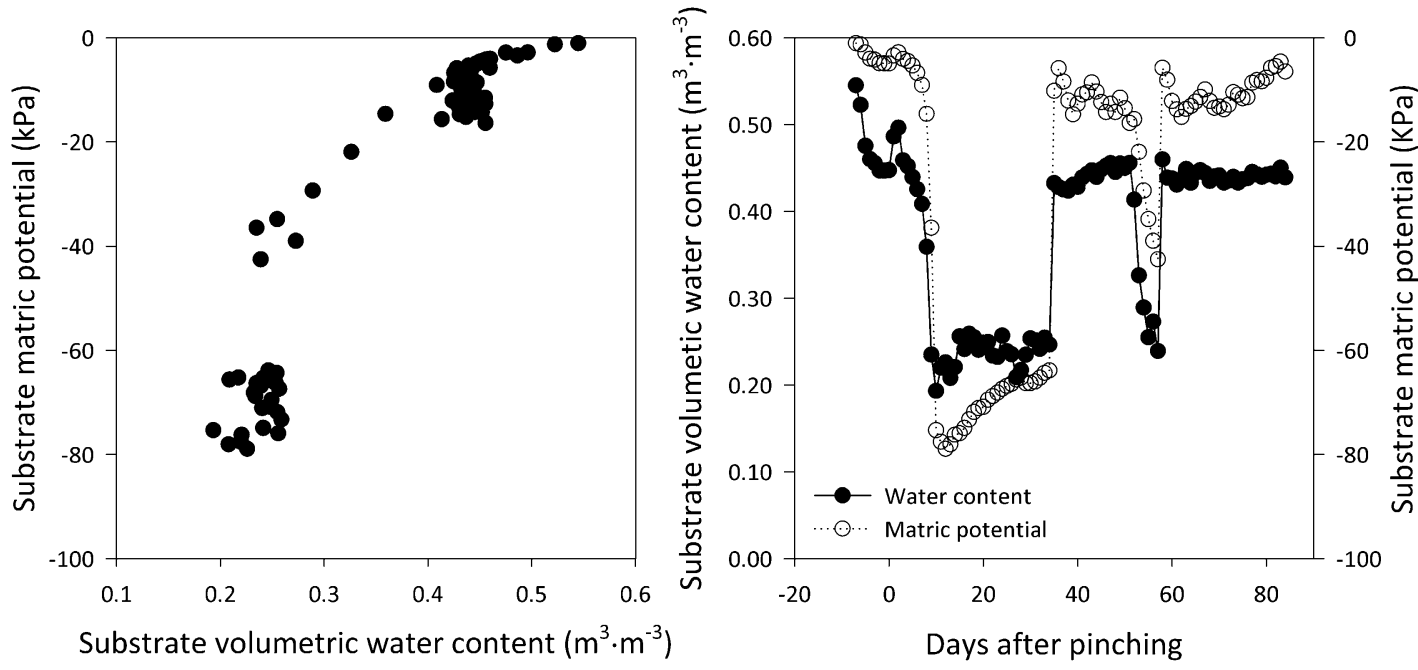

Fig. 4. The relationship between substrate volumetric moisture content $(\theta)$ and substrate matric potential measured in the same pot, because $\theta$ was altered between 0.40 and $0.20 \mathrm{~m}^{3} \cdot \mathrm{m}^{-3}$ (left) and substrate volumetric water content and matric potential over $90 \mathrm{~d}$ from $7 \mathrm{~d}$ before pinching to the end of the study.

elongate more than internodes closer to the inflorescence, the overall elongation rate of the branch is fairly stable over a prolonged period. Later in the production cycle, more internodes are elongating simultaneously and the effect of multiple internode elongation at the same time compensates for the reduced length of these distal internodes (Berghage and Heins, 1991). Plant height did not increase during the last $23 \mathrm{~d}$ of the production cycle (Fig. 1D). The final plant height in the $35.6-\mathrm{cm}$ target height treatment was $11.4 \mathrm{~cm}$ less $(39.8 \mathrm{~cm})$ than that of the control plants $(51.2 \mathrm{~cm})$ but still exceeded the final target height (Fig. 2). These results suggest that there are limits to how much height control can be achieved using WD. For 'Classic Red', this limit is a final height of $\approx 39$ to $40 \mathrm{~cm}$ under the environmental and cultural conditions of this study. This raises the question of whether a $\theta$ lower than $0.20 \mathrm{~m}^{3} \cdot \mathrm{m}^{-3}$ might result in more height control and how that would affect plant quality. 'Classic Red' is considered a vigorous cultivar (Currey and Lopez, 2011), so WD may result in lower heights in less vigorous cultivars.

Irrigation. The drip irrigation system maintained $\theta$ close to the thresholds of 0.40 and $0.20 \mathrm{~m}^{3} \cdot \mathrm{m}^{-3}$. It took $\approx 2 \mathrm{~d}$ for $\theta$ to drop from 0.40 to $0.20 \mathrm{~m}^{3} \cdot \mathrm{m}^{-3}$ on initiation of WD (Fig. 3). There was a close relationship between $\theta$ and matric potential, regardless of environmental conditions or plant growth. Substrate matric potential stayed at $\approx-5 \mathrm{kPa}$ when $\theta$ was kept at $0.40 \mathrm{~m}^{3} \cdot \mathrm{m}^{-3}$ (Fig. 4). At WD initiation, the substrate matric potential dropped gradually as $\theta$ decreased from 0.40 to $0.30 \mathrm{~m}^{3} \cdot \mathrm{m}^{-3}$. At these $\theta \mathrm{s}$, the matric potential ranged from -4 to $-30 \mathrm{kPa}$. As $\theta$ decreased further, the matric potential dropped quickly, to $-36 \mathrm{kPa}$ at $0.24 \mathrm{~m}^{3} \cdot \mathrm{m}^{-3}$ and $-75 \mathrm{kPa}$ at $0.20 \mathrm{~m}^{3} \cdot \mathrm{m}^{-3}$. When WD was stopped, the matric potential increased gradually toward $-5 \mathrm{kPa}$ as the $\theta$ increased from 0.20 to $0.40 \mathrm{~m}^{3} \cdot \mathrm{m}^{-3}$ (Fig. 4). The abrupt change in matric potential as the substrate dries out is consistent with previous reports that soilless substrates hold most of the plant available water within a narrow matric potential range ( -1 to $-20 \mathrm{kPa}$ ) (Kiehl et al., 1992; Raviv et al., 2002), because of the many large pores in soilless substrates. However, poinsettias still grew at a matric potential of $-75 \mathrm{kPa}$, contrary to previous reports that water in soilless substrates becomes unavailable to plants at matric potentials below $-20 \mathrm{kPa}$ (Kiehl et al., 1992; Milks et al., 1989; Murray et al., 2004). Earlier studies put the limits of available water at even higher matric potential; de Boodt and Verdonck (1972) classified water held at a matric potential below $-10 \mathrm{kPa}$ to be unavailable, although this was not based on plant responses. Because matric potential is a more direct indicator of substrate water availability than $\theta$, these matric potential values can be used as guidelines when using this approach to height control for plants grown in substrates with different hydraulic properties than the peat-perlite mix used in this study. However, recent studies have stressed the importance of considering plant species and substrate hydraulic conductance when predicting plant-available water (Lobet et al., 2014; O'Meara et al., 2014), so $\theta$ or matric potential levels that effectively control plant height may be species- and substratedependent.

Daily irrigation volume. The daily irrigation volume of the control plants increased from -25 to $42 \mathrm{~d}$ after pinching, peaking at $\approx 300 \mathrm{~mL} / \mathrm{plant} / \mathrm{d}$. Water use declined from Day 45 to Day 84 as the plants started to flower (Fig. 5). The control plants received more water from the middle to end of the study than the smaller, WD-treated plants. Large differences in daily irrigation volume between control and treatment plants occurred during WD application (Fig. 5). Plants did not get watered during the first few days of WD as the substrate dried out to a $\theta$ of $0.20 \mathrm{~m}^{3} \cdot \mathrm{m}^{-3}$. After a $\theta$ of $0.20 \mathrm{~m}^{3} \cdot \mathrm{m}^{-3}$ was reached, the irrigation applied enough water to maintain $\theta$ at $0.20 \mathrm{~m}^{3} \cdot \mathrm{m}^{-3}$, i.e., the irriga- tion amount is equivalent of plant water use under WD. Irrigation volume was low during WD as compared with when the $\theta$ threshold was set at $0.40 \mathrm{~m}^{3} \cdot \mathrm{m}^{-3}$, suggesting that drought-induced stomatal closure reduced plant water use. On days when WD was ended and the $\theta$ threshold was reset to $0.40 \mathrm{~m}^{3} \cdot \mathrm{m}^{-3}$, frequent irrigation was needed to raise the $\theta$ back to $0.40 \mathrm{~m}^{3} \cdot \mathrm{m}^{-3}$. This resulted in spikes in the irrigation volume (Fig. 5). It took less than $1 \mathrm{~d}$ for $\theta$ to return to $0.40 \mathrm{~m}^{3} \cdot \mathrm{m}^{-3}$. Daily water use was also affected by environmental variables, especially DLI; generally water use was low on days with low DLI (e.g., DLI of 11 to $13 \mathrm{~mol} \cdot \mathrm{m}^{-2} \cdot \mathrm{d}^{-1}$ at $-8,-7$, 25,26 , and $27 \mathrm{~d}$ after pinching).

Total irrigation volume. The cumulative irrigation volume increased with increasing target height with control plants (final height of $51.2 \mathrm{~cm}$ ) receiving the largest total irrigation volume $(14.1 \mathrm{~L} /$ plant $)$. Plants with target heights of $43.2,39.4$, and $35.6 \mathrm{~cm}$ used 9.0, 6.5, and 5.0 L/plant, respectively. The 39.4- $\mathrm{cm}$ treatment was exposed to WD for 12 more days than the $43.2-\mathrm{cm}$ treatment and this resulted in a $28 \%$ reduction in total irrigation volume and a $5 \%$ reduction in height (Fig. 2). Total irrigation volume was decreased by $45 \%$ with a target height of $35.6 \mathrm{~cm}$ as compared with $43.2 \mathrm{~cm}$ (Fig. 2). This $45 \%$ reduction in water use resulted in only an $8 \%$ reduction in plant height.

Number of nodes and internode length. The reduction in plant height resulting from application of WD can either be explained by a reduction in the number of nodes (Pace et al., 1999) or internodal length (Carvalho et al., 2002; Pearson et al., 1995). The number of nodes on the dominant stem of each plant showed no correlation with plant height and inconsistent treatment effects (Fig. 6). Internodal length showed more consistent treatment effects than the number of nodes. Control plants had longer internodes than WD-treated plants and a target height of $43.2 \mathrm{~cm}$ resulted in longer internodes than 35.6- and 39.4-cm target heights 
(Fig. 6). There was a strong relationship between internode length and plant height (Fig. 7). The reduction in internode length with an increase in duration and frequency of WD is not surprising, because WD affects cell expansion (Frensch and Hsiao, 1995; Sharp, 2002), which in turn affects internode elongation.

Shoot dry weight. The reduction in shoot dry weight showed a similar trend as plant height. The two lower target heights treatments, 35.6 and $39.4 \mathrm{~cm}$, resulted in the lowest shoot dry weight followed by the $43.2-\mathrm{cm}$ treatment, and control plants had the largest shoot dry weight (Fig. 6). Reductions in shoot dry weight at lower $\theta$ levels, similar to the $0.20-\mathrm{m}^{3} \cdot \mathrm{m}^{-3}$ WD level applied in this study, have been reported in a variety of species, including American alumroot (Heuchera americana) (Garland et al., 2012), Hibiscus acetosella (Bayer et al., 2013), and petunia (Petunia $\times$ hybrida) (van Iersel et al., 2010).

Water deficit caused a larger reduction in shoot dry weight than plant height. Shoot dry weight:height ratio, which can be used as a measure of compactness, was $0.56,0.55$,

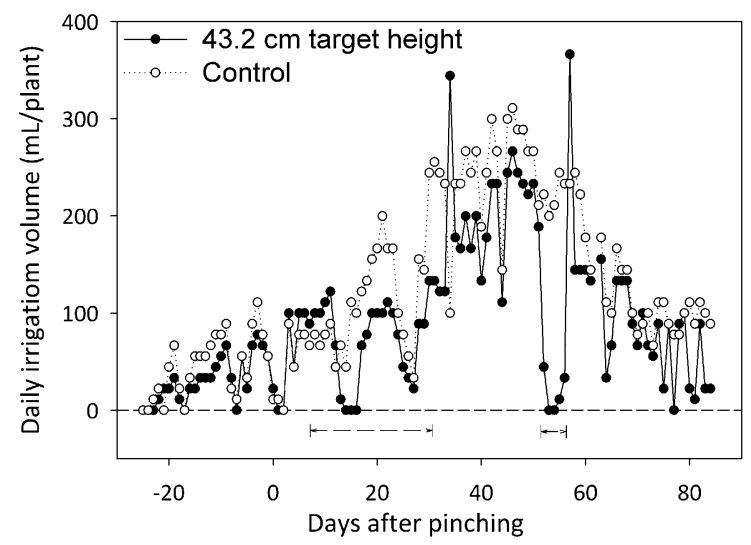

Fig. 5. Daily irrigation volume of representative plants during sufficient irrigation (control, substrate water content of $0.40 \mathrm{~m}^{3} \cdot \mathrm{m}^{-3}$ ) and water deficit application (with a 43.2-cm target height). The arrows indicate periods of WD application and the peaks on Days 34 and 57 (left) represent days when substrate water content was increased from 0.20 to $0.40 \mathrm{~m}^{3} \cdot \mathrm{m}^{-3}$.

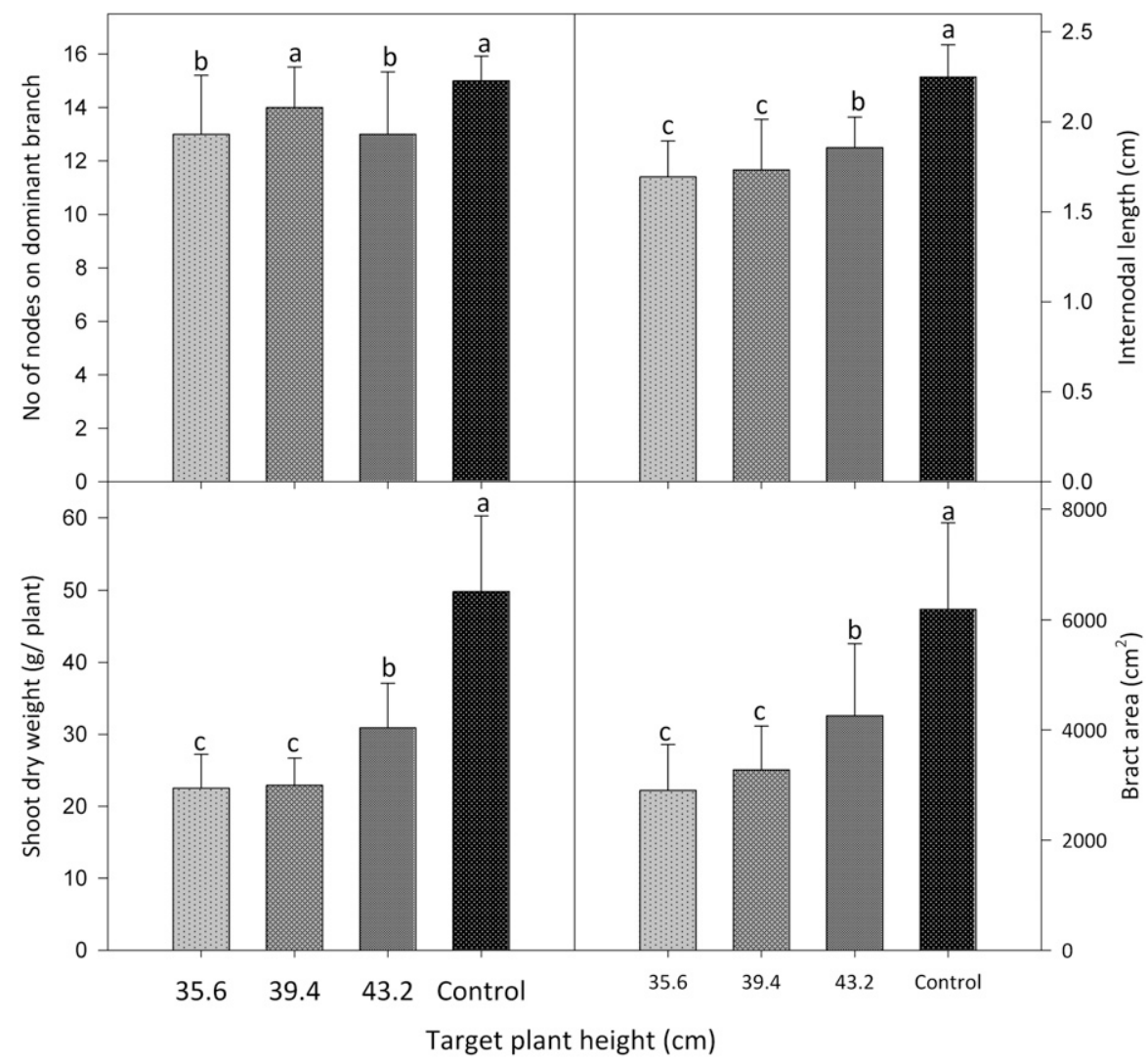

Fig. 6. The number of nodes and average internode length on the dominant branch and total shoot dry weight and bract area of poinsettia. Bars (means \pm SD) with the same letter are not significantly different according to Tukey's test $(P=0.05)$.
0.71 , and $0.97 \mathrm{~g} \cdot \mathrm{cm}^{-1}$ in the $35.6-, 39.4-$, and 43.2-cm target height and control treatments, respectively. Similar results have been reported previously with salvia (Salvia splendens) and marigold (Tagetes patula) (Burnett et al., 2005; van Iersel and Nemali, 2004). Compared with control plants, there was a $55 \%, 54 \%$, and $38 \%$ reduction in shoot dry mass and a $22 \%, 19 \%$, and $15 \%$ reduction in height in the 35.6-, 39.4-, and 43.2-cm target height treatments, respectively. This suggests that shoot biomass accumulation is more sensitive to WD than plant height. Water deficit may affect a variety of plant growth and morphological features such as number and size of leaves and canopy density, hence reducing shoot biomass (Burnett and van Iersel, 2008; Niu et al., 2006).

Bract area. Bracts are the main ornamental part of poinsettias and bract area or size can be affected by height regulation practices such as spray applications of PGRs in the later stages of development (Currey and Lopez, 2011; Niu et al., 2002). Water deficit application reduced bract area of poinsettias and this reduction in bract area increased with an increase in duration of WD application. Relative to control plants, bract area was reduced by $53 \%, 47 \%$, and $31 \%$ in 35.6 -, $39.4-$, and $43.2-\mathrm{cm}$ target height treatments, respectively. This is consistent with the findings of Barrett and Nell (1982), who reported that increasing the irrigation interval, allowing the substrate to dry out more between irrigations, reduced bract dry weight. Nowak and Strojny (1998) reported that drought stress (matric potential of $-50 \mathrm{kPa}$ throughout the entire production period) reduces the dry weight, bract area, and number of bracts of poinsettia. Bract area reduction resulting from WD is not surprising, because bracts are modified leaves and leaf expansion is often affected in the early stages of drought stress (Fernandez et al., 2002). However, in a previous study, we saw no effect of the same severity of WD on the size of individual bracts, perhaps because plants were exposed to WD for a shorter period in that study (13 vs. $23 \mathrm{~d}$; Alem, 2014). Total bract area was not quantified in our previous study, but it seems likely that effects of WD on bract size and total area depend on both the duration and timing of WD. To minimize the effect of WD on bract size and the associated reduction in quality, WD should be avoided during bract elongation. However, reductions in bract area may not always have a negative impact on plant quality. Currey and Lopez (2011) argue that the proportion between bract area and overall plant size is a better indicator of plant quality than bract area per se.

\section{Conclusions}

Application of controlled WD can be used to regulate poinsettia stem elongation. Water deficit suppresses poinsettia stem elongation by reducing the length of the shoot internodes. The required frequency and duration of WD application is dependent on the 


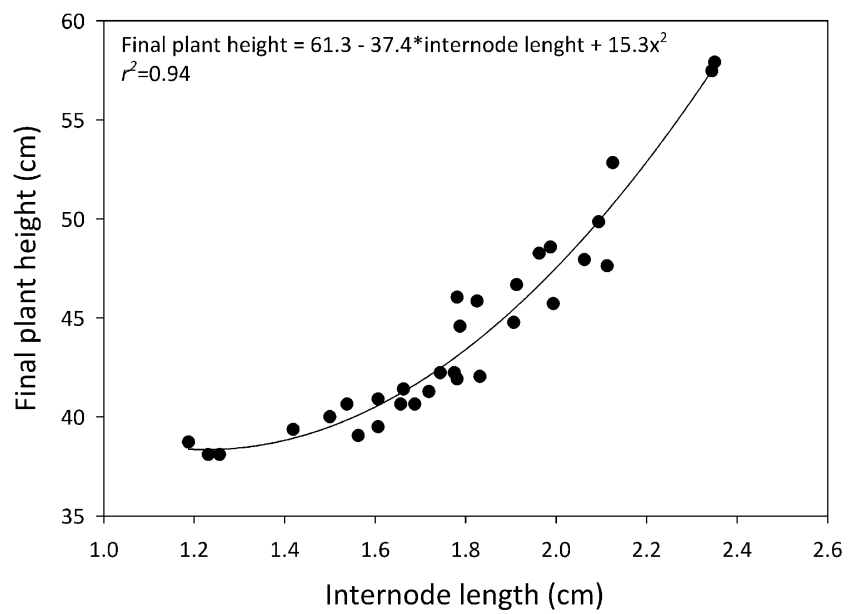

Fig. 7. The relationship between final plant height and the average internode length measured on a dominant stem of poinsettia. Data from all 32 experimental units are shown. Each data point represents the average of two plants.

desired final target height. However, there are limits to how much height control can achieved. The 35.6- $\mathrm{cm}$ target height was not achieved, despite applying WD throughout most of the production period. This sustained WD reduced plant height of poinsettia 'Classic Red' by $\approx 11 \mathrm{~cm}$, resulting in a final height of 39 to $40 \mathrm{~cm}$. Application of WD may also reduce bract area, which is not unexpected given the overall reduction in plant size.

\section{Literature Cited}

Alem, P. 2014. Irrigation, fertilization and nonchemical plant growth regulation in greenhouse production. PhD diss., Univ. of Georgia, Athens, GA

Barrett, J.E. and T.A. Nell. 1982. Irrigation interval and growth retardants affect poinsettia development. Proc. Florida State Hort. Soc. 95:167169.

Bayer, A., I. Mahbub, M. Chappell, J. Ruter, and M.W. van Iersel. 2013. Water use and growth of Hibiscus acetosella 'Panama Red' grown with a soil moisture sensor controlled irrigation system. HortScience 48:980-987.

Berghage, R.D. and R.D. Heins. 1991. Quantification of temperature effects on stem elongation in poinsettia. J. Amer. Soc. Hort. Sci. 116:14-18.

Bierman, P.M., C.J. Rosen, and H.F. Wilkins. 1990. Leaf edge burn and axillary shoot growth of vegetative poinsettia plants: Influence of calcium, nitrogen form, and molybdenum. J. Amer. Soc. Hort. Sci. 115:73-78

Burnett, S.E., S.V. Pennisi, P.A. Thomas, and M.W. van Iersel. 2005. Controlled drought affects morphology and anatomy of Salvia splendens. J. Amer. Soc. Hort. Sci. 130:775-781.

Burnett, S.E. and M.W. van Iersel. 2008. Morphology and irrigation efficiency of Gaura lindheimeri grown with capacitance-sensor controlled irrigation. HortScience 43:1555-1560.

Carvalho, S.M.P., E. Heuvelink, R. Cascais, and O. van Kooten. 2002. Effect of day and night temperature on internode and stem length in chrysanthemum: Is everything explained by DIF. Ann. Bot. (Lond.) 90:111-118.

Chappell, M., S.K. Dove, M.W. van Iersel, P.A. Thomas, and J. Ruter. 2013. Implementation of wireless sensor networks for irrigation control in three container nurseries. HortTechnology 23:747-753.

Clifford, S.C., E.S. Runkle, F.A. Langton, A. Mead, S.A. Foster, S. Pearson, and R.D. Heins 2004. Height control of poinsettia using photoselective filters. HortScience 39:383-387.

Currey, C.J. and R.G. Lopez. 2011. Early flurprimidol applications suppress final height of four poinsettia cultivars. HortTechnology 21:35-40.

de Boodt, M. and O. Verdonck. 1972. The physical properties of the substrates used in horticulture. Acta Hort. 26:37-44.

Faust, J.E. and R.D. Heins. 1996. Axillary bud development of poinsettia 'Eckespoint Lilo' and 'Eckespoint Red Sails' (Euphorbia pulcherrima Willd.) is inhibited by high temperatures. J. Amer. Soc. Hort. Sci. 121:920-926.

Faust, J.E., P.C. Korczynski, and R. Klein. 2001 Effects of paclobutrazol drench application dates on poinsettia height and flowering. HortTechnology 11:557-560.

Fernandez, R.J., M. Wang, and J.F. Reynolds. 2002. Do morphological changes mediate plant responses to water stress? A steady-state experiment with two C4 grasses. New Phytol. 155:79-88.

Fisher, P.R. and R.D. Heins. 1995. A processcontrol approach to poinsettia height control. HortTechnology 5:57-63.

Frensch, J. and T.C. Hsiao. 1995. Rapid response of the yield threshold and turgor regulation during adjustment of root growth to water stress in Zea mays. Plant Physiol. 108:303-312.

Garland, K.F., S.E. Burnett, M.E. Day, and M.W. van Iersel. 2012. Influence of substrate water content and daily light integral on photosynthesis, water use efficiency, and morphology of $\mathrm{Heu}$ chera americana. J. Amer. Soc. Hort. Sci. 137:57-67.

Hammond, H.E., R.K. Schoellhorn, S.B. Wilson, and J.G. Norcini. 2007. Differing blanket flower cultivar and ecotype responses to plant growth regulators. Hort Technology 17:552-556.

Kiehl, P.A., J.H. Liel, and D.W. Buerger. 1992 Growth response of Chrysanthemum to various container medium moisture tensions levels. J. Amer. Soc. Hort. Sci. 117:224-229.

Latimer, J.G., P. Lewis, and P.A. Thomas. 1999 Plant growth regulator effects on height and landscape performance of perennial bedding plants. Acta Hort. 504:83-91.

Lewis, K.P., J.E. Faust, J.D. Sparkman, and L.W Grimes. 2004. The effect of daminozide and chlormequat on the growth and flowering of poinsettia and pansy. HortScience 39:1315-1318.

Liptay, A., P. Sikkema, and W. Fonteno. 1998. Transplant growth control through water deficit stress: A review. HortTechnology 8:540-543.

Lobet, G., V. Couvreur, F. Meunier, M. Javaux, and X. Draye. 2014. Plant water uptake in drying soils. Plant Physiol. 164:1553-1555.

Milks, R.R., W.C. Fonteno, and R.A. Larson. 1989 Hydrology of horticultural substrates: II. Predicting physical properties of substrate in containers. J. Amer. Soc. Hort. Sci. 114:53-56.

Moe, R., T. Fjeld, and L.M. Mortensen. 1992. Stem elongation and keeping quality in poinsettia (Euphorbia pulcherrima Willd.) as affected by temperature and supplementary lighting. Sci. Hort. 50:127-136.

Murray, J.D., J.D. Lea-Cox, and D.S. Ross. 2004 Time domain reflectometry accurately monitors and controls irrigation water applications in soilless substrates. Acta Hort. 633:75-82.

Nemali, K.S. and M.W. van Iersel. 2006. An automated system for controlling drought stress and irrigation in potted plants. Sci. Hort 110:292-297.

Niu, G., R. Heins, and W. Carlson. 2002. Using paclobutrazol to control the height of poinsettia 'Freedom'. HortTechnology 12:232-236.

Niu, G., D.S. Rodriguez, L. Rodriguez, and W. Mackay. 2007. Effect of water stress on growth and flower yield of Big Bend bluebonnet. HortTechnology 17:557-560.

Niu, G., D.S. Rodriguez, and Y. Wang. 2006 Impact of drought and temperature on growth and leaf gas exchange of six bedding plant species under different greenhouse conditions. HortScience 41:1408-1411.

Nowak, J.S. and Z. Strojny. 1998. Effect of soil water potential on poinsettia plants. Acta Hort. 458:273-276

O'Meara, L., M.W. van Iersel, and M.R. Chappell 2014. Water use of Hydrangea macrophylla and Gardenia jasminoides in response to a gradually drying substrate. HortScience 49:493498.

Pace, P.F., H.T. Cralle, S.H.M. El-Halawany, J.T Cothren, and S.A. Senseman. 1999. Droughtinduced changes in shoot and root growth of young cotton plants. J. Cotton Sci. 3:183-187.

Pearson, S., P. Hadley, and A.E. Wheldon. 1995. A model of the effect of day and night temperature on the height of chrysanthemum. Acta Hort. 378:71-80.

Raviv, M., R. Wallach, A. Silber, and A. Bar-Tal. 2002. Substrates and their analysis, p. 25-101. In: Savvas, D. and H.C. Passam (eds.). Hydroponic production of vegetables and ornamentals. Embryo Publ., Athens, Greece.

Sharp, R.E. 2002. Interaction with ethylene: Changing views on the role of abscisic acid in root and shoot growth responses to water stress. Plant Cell Environ. 25:211-222.

van Iersel, M.W., M.R. Chappell, and J. Lea-Cox. 2013. Sensors for improved efficiency of irrigation in greenhouse and nursery production. HortTechnology 23:735-746.

van Iersel, M.W., S. Dove, J.G. Kang, and S.E. Burnett. 2010. Growth and water use of petunia as affected by substrate water content and daily light integral. HortScience 45:277-282.

van Iersel, M.W. and K.S. Nemali. 2004. Drought stress can produce small, but not compact marigolds. HortScience 39:1298-1301.

Zhen, S., S.E. Burnett, M.E. Day, and M.W. van Iersel. 2014. Effects of substrate water content on morphology and physiology of rosemary, Canadian columbine, and cheddar pink HortScience 49:486-492. 